\title{
EFFECTS OF INFESTATION BY COWPEA APHID (HOMOPTERA: APHIDIDAE) ON DIFFERENT GROWTH STAGES OF RESISTANT AND SUSCEPTIBLE COWPEA CULTIVARS
}

\author{
I. BILLY ANNAN ${ }^{1}$, K. N. SAXENA ${ }^{2}$, G. A. SCHAEFERS ${ }^{3}$ and WARD M. TINGEY ${ }^{4}$ \\ ${ }^{1}$ Du Pont Agricultural Products, Stine-Haskell Research Centre, Elkton Road, \\ P.O. Box 30, Newark, DE 19714-0030, USA; \\ ${ }^{2}$ International Centre of Insect Physiology and Ecology, P.O. Box 30772, Nairobi, Kenya; \\ ${ }^{3} \mathrm{New}$ York State Agricultural Experiment Station/Cornell University, \\ Department of Entomology, Box 462, Geneva, N.Y. 14456-0462, USA; \\ ${ }^{4}$ Department of Entomology, Cornell University, Insectary, Tower Road, Ithaca, \\ N.Y. 14853-2604, USA
}

(Received 2 June 1994; accepted 7 October 1994)

\begin{abstract}
Field studies were conducted to characterise the effects of infestations by adult and nymphal stages of cowpea aphid, Aphis craccivora Koch, on the growth and yield of cowpea, Vigna unguiculata (L.) Walp. Seedling, flowering, and podding stage plants of aphid-resistant (cv. ICV. 12) and aphid-susceptible (cv. ICV-1) cowpea cultivars were used in the studies. Four treatments (consisting of infestations with adult and nymphal aphids, caged controls and uncaged controls) were administered on plants for 22 days post-treatment. Eight parameters of crop success were measured: extended leaf heights (ELH); plant mortality; incidence of sooty mould; incidence and abundance of natural enemy species; crop growth parameters (net assimilation rate, [NAR] in g/ $\mathrm{dm}^{2} / \mathrm{day}$, and crop growth rate [CGR] in $\mathrm{g} / \mathrm{dm}^{2}$ land surface/day); and plant yields (seeds per pod, weight per seed). Data were analysed using analysis of variance (ANOVA), orthogonal contrasts and $95 \%$ confidence intervals (C.I.). There were no significant $(P>0.05)$ differences between adult and nymphal infestations or between caged and uncaged controls, so the respective sets of data were combined for comparisons of aphid infestations with control treatments. Infestations caused severe plant stunting and other growth deformities, drastic yield reductions, higher plant mortality, greater incidence of natural enemies and abundance of Cheilomenes spp. on cv. ICV1 than on cv. ICV-12, and on infested and uninfested plants. Aphid infestations did not significantly affect the incidence of sooty mould on plants of cv. ICV-12 or cv. ICV-1.
\end{abstract}

Key Words: Aphis craccivora, Homoptera, Cheilomenes spp., aphid stages, orthogonal contrasts, net assimilation rate, ICV-12, aphid resistance

Résumé-Des études furent menées sur terrain pour caractériser les effets des infestations des stades adults et nymphal de l'aphide du niébé, Aphis craccivora Koch, sur la croissance et le rendement du niébé, Vigna unguiculata (L.) Walp. Les plantes aux stades de plantule, de floraison et de gousse d'une variété résistante de niébé (cv. ICV-12) et une autre susceptible (cv. ICV-1) ont été utilisées dans cette étude. Quatre traitements (consistant à infester les aphides adultes, les nymphes, les témoins configés en cage et les témoins non encagés) ont été administrés sur des plantes 22 jours aprés traitement. Huit paramétres pour caractériser le développement réussi de la plante ont été mesurés: accroissement de la hauteur des feuilles; mortalité de plantes; incidence du dépôt de suie; incidence et abondance d'ennemis naturels; paramétres de croissance de la plante (taux net d'assimilation [TNA] en $\mathrm{g} / \mathrm{dm}^{2} / \mathrm{jr}$ et taux de croissance de la plante [TCP] en g/ $\mathbf{d m}^{2} /$ surface de terre/jr); et rendements de la plante (nombre de graines par gousse, poids par graine). Les données ont été analysées à l'aide de l'analyse de variance (ANOVA), suivie de contrastes orthogonaux pour $95 \%$ d'intervalle de confiance. Il n'y a pas eu de difference significative ( $P>\mathbf{0 . 0 5}$ ) entre témoins en cage et ceux libres; par conséquent, les données ont été groupées ensemble pour comparer les infestations d'aphides avec les témoins. Les infestations ont 


\begin{abstract}
causé un sévére rabougrissement de la plante et d'autres malformations de croissance, des réductions drastiques de rendement, une mortalité, une incidence d'ennemis naturels et une abondance de Cheilomenes spp. sur cv. ICV-1 plus éléves que sur cv. ICV-12 ainsi que sur des plantes infestées et non infestées. On en a conclu que les infestations des nymphes et adultes de l'aphide du niébé ont causé des effets adverses significatifs sur la performance du niébé et que les réactions de la plante ont varié en fonction des variétés et de différents stages de croissance au sein d'une même variété.
\end{abstract}

Mot Clés: Aphis craccivora, Homoptera, Chilomenes spp., stades d'aphide, contrastes orthogonaux, taux net d'assimilation, ICV-12, résistance aux aphides

\section{INTRODUCTION}

Cowpea, Vigna unguiculata (L.) Walp., is a cosmopolitan pulse crop that is an important staple in human diets in many tropical and sub-tropical regions of the world (Singh, 1975; Okigbo, 1979). It has significant medicinal, agronomic, soil management and pest control value (Rachie, 1973; Appiah and Thompson, 1974 and Brockman, 1975). Cowpea aphid, Aphis craccivora Koch, also known as groundnut aphid or black legume aphid, is the most important aphid pest of cowpea, and also a serious pest of legumes worldwide. It damages cowpea at all phases of the crop phenology, from early seedling to flowering, pod-setting and seed-fill stages.

Aphis craccivora injures plants through the sucking of sap during feeding, and in the process often injects "toxins" or transmits disease-causing viruses into plants. Direct aphid damage results from mechanical piercing of plants and draining of sap from shoots, pods and seeds, or injecting deleterious saliva into plants. The aphid causes severe direct damage to cowpea pods at young and mid-fill stages. However, tolerance and susceptibility of plants to the aphid attack may be modulated by differential varietal resistance (Ofuya, 1993) and by plant growth stage (MacFoy and Dabrowski, 1984; Ofuya, 1989). Indirect damage by the aphid is through the transmission of virus diseases to plants during feeding (Edwardson and Christie, 1986). Aphis craccivora transmits over 30 viruses to cowpea and other legumes (Blackman and Eastop, 1984). One of the most common and serious cowpea diseases vectored by $A$. craccivora is the aphid-borne mosaic (CAbMV) which causes significant yield reductions and total crop losses in cowpea (Raheja and Leleji, 1974). Damage by aphid-transmitted viruses is often additive to direct damage by aphids.

Atiri et al. (1986) mentioned that A. craccivora and $A$. gossypii are among the most efficient vectors of CAbMV, and thus greatly contribute to spread of the disease. The authors indicated that alate aphid activity rather than abundance was more important in virus transmissibility. They also reported a positive correlation between the number of alates and the incidence of CAbMV on plants of susceptible cowpea cultivars, but not on resistant lines. Large colonies of apterae were usually more abundant on plants of susceptible cultivars, but individual apterae and small colonies were widely dispersed on resistant lines.

Another type of indirect damage by the aphid on cowpea is the promotion of growth of sooty moulds caused by saprophytic fungi with dark hyphae which form superficial brown-black colonies on leaves of host plants (Hughes, 1976). Sticky honeydew produced by aphids provides a rich medium to entrap fungal spores and promote growth of moulds. This results in the reduction of effective leaf area for light absorption, and thus significantly limits photosynthetic efficiency.

Aphis craccivora has significantly adverse impact on other aspects of the physiology of cowpea and other legumes. Infestations by the aphid significantly reduced plant leaf area, dry weight, relative growth rate, carbon use efficiency and levels of $\mathrm{N}$ and $\mathrm{P}$ in legumes (Hawkins et al., 1986b, c, d) while dark respiration was significantly increased (Hawkins et al., 1987b). Aphid imbibition of plant sap and injection of saliva into plants during feeding by aphids altered photosynthate partitioning patterns in shoots, reduced flux of phloem translocate to roots, and induced assimilate sources in plants to become sinks (Hawkins et al., 1987a).

The impact of plant resistance on the bionomics of A. craccivora on different growth stages of cowpea, particularly at flowering and podding stages has not been well-documented. The major objective of this study was to investigate the effects of cowpea aphid infestations on different plant stages of an aphid-resistant cowpea cultivar (cv. ICV-12) and an aphid-susceptible cultivar (cv. ICV-1), and the translation of those effects into crop growth and yield performance. Overall, this study was designed to detect the impact of selection of resistant or susceptible crop germplasm, aphid treatments, plant stage at aphid infestation and the interactions of those factors on crop growth and yield, as well as other characteristics associated with cowpea crop success. 


\section{MATERIALS AND METHODS}

This study was conducted at the Mbita Point Field Station (MPFS) of the International Centre of Insect Physiology and Ecology (ICIPE) in Kenya, over three cowpea planting seasons. The first season was from February to May 1990; experiments were repeated from July to November 1990, and January to April 1991.

The experiments were designed as split splitplots in a randomised complete block. Whole-plots consisted of three growth stages of cowpea (second trifoliate seedlings, flowering and podding). Subplots consisted of two cowpea cultivars, while the split sub-plots consisted of four levels of aphid infestations (five newly-emerged adult aphids, five third-instar nymphs, caged controls and uncaged controls). The cowpea cultivars used were an aphidresistant variety (cv. ICV-12) and an aphidsusceptible variety (cv. ICV-1) which were registered and released by ICIPE (Pathak 1988; Pathak and Olela 1986).

There were four blocks in each experiment, with each block measuring $4 \mathrm{~m}$ long by $20 \mathrm{~m}$ wide. Each experimental plot size was $22 \mathrm{~m}$ by $20 \mathrm{~m}$, with unplanted borders of $2 \mathrm{~m}$ between blocks and $1 \mathrm{~m}$ between plots, to minimise inter-plot interference. Planting distances were $50 \mathrm{~cm}$ between rows and 30 $\mathrm{cm}$ within rows. There were 7 rows per plot and 13 plants per row in each planting, to give a planting density of ca. 67,000 plants/ha. Five plants per row were selected for treatment at crop emergence. Treatments were randomly assigned to plants at the specified growth stages. Planting of all plots in each experiment was done on the same day.

Aphids used in infestations were generations obtained from a small colony originally collected in February 1990 from fields around the ICIPE-MPFS. The colonies were maintained in the greenhouse at $27 \pm 1^{\circ} \mathrm{C}, 50-80 \% \mathrm{RH}$ and a $12: 12$ (L:D) cycle on susceptible VITA-7 cowpea. Fresh cowpea seedlings were regularly added to maintain colony vigour. Treatments were assigned to individual plants which were confined in cages constructed of a 32 mesh per $\mathrm{mm}^{2}$ No-See-Um ${ }^{8}$ polyester fabric supported on metal frames measuring $30 \times 30 \times 60 \mathrm{~cm}$. Aphids were infested on plants at the specified growth stages and were maintained for 22 days. This duration was chosen to simulate the duration of a generation of $A$. craccivora on cowpeas in the field. Treatments of podding-stage plants were maintained for 22 days; however, in the case of plants infested at podding stage, treatments were maintained until crop physiological maturity when pods started to dry. After the stipulated durations, aphids were removed by spraying with permethrin as Ambush ${ }^{\circledR}$
(ICl-Twiga Chemical Industries, Nairobi, Kenya) at a volumetric rate of $0.0051 / 1$ of solution. Sprays were done with a 2-1 knapsack sprayer Model RY-2 $819571^{\circledR}$ (Hardi Co. Ltd., Nairobi, Kenya) equipped with flat spray nozzle no. $4110-12$ calibrated at a delivery rate of $0.6 \mathrm{l} / \mathrm{min}(25 \mathrm{fl} \mathrm{oz})$, and a spray pressure of ca. $2.1 \mathrm{~kg} / \mathrm{cm}^{2}$ ( 29 p.s.i.).

Extended leaf heights (ELH) of plants were measured and recorded as the above-ground plant height from the base to the longest growing tip. Counts of aphid nymphs, apterous and alate adults were taken at 7, 12,17 and 22 days after infestation (DAI). Counts of different aphid morphs were recorded at each date of observation. Data on ELH were analysed using repeated measures model to test for interactions of date of observation with the subplot and split sub-plot factors. Plant mortality, incidence of sooty mould, and incidence and abundance of natural enemy species of the aphid were recorded. The crop growth parameter recorded was net assimilation rate or unit leaf rate (NAR in g/ $\mathrm{dm}^{2} /$ day) which represents the net gain of mainly photosynthetic assimilate per unit of area and time. This parameter was estimated using the ratio between measured plant dry weights and leaf areas obtained by destructive sampling of designated plants within the 22 days between the date of infestation assignments and the date of treatment removal. Crop growth rate of total biomass (CGR in $\mathrm{g} / \mathrm{dm}^{2}$ land area/day) represents the gain in weight of a community of plants on a unit of land in a unit of time (Gardner et al., 1985). The parameter was estimated as a product of NAR and the dimensionless leaf area index. After harvest, seeds per pod and weight per seed were recorded as plant yields.

Data were analysed using standard analysis of variance (ANOVA) in JMP ${ }^{\circledR}$ Statistics and Graphics Guide, v. 3.0.2 (SAS Institute, 1994). Where significant $(\mathrm{P} \leq 0.05)$ interactions were detected, orthogonal contrasts and $95 \%$ confidence intervals (C.I.) were used to analyse specific differences between the effects of adult and nymphal aphids, and between caged and uncaged controls. Due to lack of normality in their distributions, data on aphid counts, plant mortality and plants infected with sooty mould were transformed using $\sqrt{ }(\mathrm{Y}+0.5)$ transformations, while aphid natural enemies data were transformed using $\log _{10}(\mathrm{Y}+1)$. Means of the transformed data were reconverted to the original scale after analyses (Snedecor and Cochran, 1980).

Since planting was done on the same day, the assignment and removal of treatments was done on different dates. Thus, observations of ELH, aphid counts and sampling of plants for growth analyses were confounded by plant stage at infestation. This prevented analysing ELH data, aphid counts and 
crop growth parameters for the overall effects of plant growth stage at infestation. Therefore, the data were analysed by plant growth stage, comparing cultivars and treatments and their interactions. The experimental design also allowed for detection of any differences between the effects of nymphal and adult aphids, and caging on plant parameters.

\section{RESULTS}

The first planting occurred in a major rainy season at MPFS, so the cumulative counts of aphid density were lower than those estimated in subsequent plantings. Nevertheless, the trends in the results obtained in all the experiments were similar, so data for the three experiments were combined and analysed.

The ANOVA indicated significant three-way interactions of date by cultivar by treatment $\left(\mathrm{F}_{3,3805}\right.$
$=3.9, \mathrm{P} \leq 0.001)$ for $\mathrm{ELH}$. There were significant $(\mathrm{P}$ $\leq 0.05$ ) two-way interactions between date of observation and cultivar (sub-plots) as well as with the treatment (split sub-plots). Since date of observation of ELH was confounded by plant growth stage at infestation, data were analysed by date of observation comparing interactions between cultivar and treatment at each plant stage.

At each plant growth stage, there were significant interactions between cultivar and treatment $(\mathrm{P} \leq$ 0.001 ). At the $95 \%$ C.I. there were no significant $(P>0.10)$ differences between infestations by adult and nymphal aphids, and between caged and uncaged controls, on plant ELH (data not shown). Therefore, data for adult and nymphal infestations were combined, and compared with the combined data for caged and uncaged controls. Orthogonal comparisons of infestations and control treatments indicated that there were no significant differences in ELH of

Table 1. Extended leaf heights (ELH, cm) of aphid-resistant (ICV-12) and aphid-susceptible (ICV-1) plants infested at seedling, flowering and podding stages and control plants, at 7,12,17 and $22 \mathrm{DAI}^{\mathrm{a}}$

\begin{tabular}{llllllr}
\hline Growth stage & Treatment & Cultivar & 7 DAI $^{\mathrm{b}}$ & $12 \mathrm{DAI}$ & $17 \mathrm{DAI}$ & $22 \mathrm{DAI}$ \\
\hline Seedling & Control & ICV-12 & $34 \pm 0.6$ & $43 \pm 2.0$ & $48 \pm 1.6$ & $54 \pm 4.2$ \\
& & ICV-1 & $33 \pm 6.7$ & $38 \pm 4.4$ & $45 \pm 3.7$ & $55 \pm 2.8$ \\
& Infested & ICV-12 & $37 \pm 4.5$ & $40 \pm 2.8$ & $48 \pm 2.9$ & $53 \pm 0.8$ \\
& & ICV-1 & $25 \pm 0.4$ & $30 \pm 1.1$ & $33 \pm 1.1$ & $33 \pm 3.0$ \\
\hline Flowering & Control & ICV-12 & $69 \pm 5.1$ & $74 \pm 3.5$ & $78 \pm 2.2$ & $86 \pm 3.1$ \\
& & ICV-1 & $77 \pm 4.5$ & $82 \pm 6.2$ & $86 \pm 11.3$ & $88 \pm 1.5$ \\
& Infested & ICV-12 & $77 \pm 6.3$ & $86 \pm 5.1$ & $88 \pm 7.1$ & $96 \pm 6.5$ \\
& & ICV-1 & $74 \pm 3.5$ & $88 \pm 3.3$ & $90 \pm 5.9$ & $93 \pm 4.4$ \\
& & ICV-12 & $84 \pm 4.1$ & $87 \pm 2.7$ & $96 \pm 4.0$ & $104 \pm 5.7$ \\
Podding & Control & ICV-1 & $77 \pm 4.7$ & $94 \pm 9.2$ & $90 \pm 0.7$ & $107 \pm 3.3$ \\
& & ICV-12 & $82 \pm 2.3$ & $88 \pm 4.1$ & $90 \pm 3.6$ & $97 \pm 4.0$ \\
& Infested & ICV-1 & $78 \pm 5.7$ & $90 \pm 2.3$ & $93 \pm 5.3$ & $100 \pm 7.9$ \\
\hline
\end{tabular}

${ }^{\text {aMeans }} \pm 95 \%$ C.I.

bDays after infestation (i.e., days after aphids and control treatments were administered on plants).

Table 2. Associations of mean number of plants infected by sooty mould, incidence and abundance of natural enemy species and plant mortality with infestations of seedling, flowering stage and podding stage plants of aphid-resistant (ICV-12) and aphid-susceptible (ICV-1) cowpea cultivars

\begin{tabular}{lllcccc}
\hline $\begin{array}{l}\text { Growth } \\
\text { stage }\end{array}$ & Treatment & Cultivar & $\begin{array}{c}\text { Sooty } \\
\text { mould }\end{array}$ & $\begin{array}{c}\text { Natural } \\
\text { enemy } \\
\text { species }\end{array}$ & $\begin{array}{c}\text { Number of } \\
\text { Cheilomenes } \\
\text { spp. }\end{array}$ & $\begin{array}{c}\text { Prop. } \\
\text { plant }^{\mathrm{a}} \\
\text { mortality }\end{array}$ \\
\hline Seedling & Control & ICV-12 & $0.34 \pm 0.07$ & $1.14 \pm 0.06$ & $2 \pm 0.3$ & 0.03 \\
& & ICV-1 & $0.42 \pm 0.08$ & $1.25 \pm 0.06$ & $8 \pm 3.8$ & 0.02 \\
& Infested & ICV-12 & $0.59 \pm 0.03$ & $1.18 \pm 0.01$ & $11 \pm 2.8$ & 0.03 \\
& & ICV-1 & $1.45 \pm 0.21$ & $2.90 \pm 0.02$ & $81 \pm 7.0$ & 0.42 \\
\hline Flowering & Control & ICV-12 & $0.20 \pm 0.06$ & $1.19 \pm 0.03$ & $3 \pm 0.8$ & 0.00 \\
& & ICV-1 & $0.28 \pm 0.09$ & $1.23 \pm 0.03$ & $20 \pm 9.4$ & 0.00 \\
& Infested & ICV-12 & $1.48 \pm 0.08$ & $1.38 \pm 0.02$ & $46 \pm 11.2$ & 0.03 \\
& & ICV-1 & $1.64 \pm 0.17$ & $3.04 \pm 0.04$ & $103 \pm 12.9$ & 0.11 \\
\hline Podding & Control & ICV-12 & $0.14 \pm 0.04$ & $1.10 \pm 0.02$ & $5 \pm 1.9$ & 0.00 \\
& & ICV-1 & $0.08 \pm 0.02$ & $1.15 \pm 0.03$ & $15 \pm 2.1$ & 0.00 \\
& Infested & ICV-12 & $1.17 \pm 0.06$ & $1.71 \pm 0.02$ & $62 \pm 8.6$ & 0.02 \\
& & ICV-1 & $1.34 \pm 0.15$ & $3.95 \pm 0.02$ & $184 \pm 10.1$ & 0.08 \\
\hline
\end{tabular}

$\mathrm{a} \sqrt{(Y+0.5)}$ transformed data, (unconverted error mean square added to squared means), means $\pm 95 \%$ C.I.

${ }^{b} \log _{10}(Y+1)$ transformed data. 
uninfested plants of ICV-12 and ICV-1 (Table 1). However, compared to the respective controls, there were significant deleterious effects of infestations on ELH of ICV-1 seedlings; the effects were not apparent on infested ICV-12 seedlings (Table 1), signifying that $A$. craccivora caused stunting in ICV-1 seedlings but not in ICV-12. Also, infestations did not effect the ELH of plants at flowering and podding stage.

Incidence and severity of sooty mould was measured by counts of the number of plants that had $20 \%$ or more of their foliage covered by the dark fungal soot. Incidence of mould was significantly $(\mathrm{P} \leq 0.01)$ greater on infested ICV-1 plants than on infested ICV-12 plants (Table 2). Moulds were observed at each plant stage, and there was no significant difference in the incidence of sooty mould on control treatments of the two cultivars. However, the problem was generally more severe on infested plants than the respective control treatments. Within ICV-1, mould infections did not change significantly across plant growth stages, but on ICV-12, the problem was least severe on seedlings. Due to the occurrence of sooty moulds even on uninfested controls, correlation of the incidence of sooty mould with the presence of aphids (infestations) or absence of aphids (control treatments) was poor and nonsignificant $(r=0.12, \mathrm{P}>0.25)$. However, the correlation of the incidence of moulds with aphid density was highly significant $(r=0.94, \mathrm{P} \leq 0.05)$.

Six species of aphid predators and parasitoids were recorded. These included coccinellid beetles, ants, wasps and mantids. Predatory coccinellids were the most common, including Cheilomenes lunata $\mathrm{F}$. and $C$. vicinia (Mulsant) which were the most predominant, as well as Coccinella spp., Scymnus sp. and two unidentified genera. There were positive correlations between aphid infestations

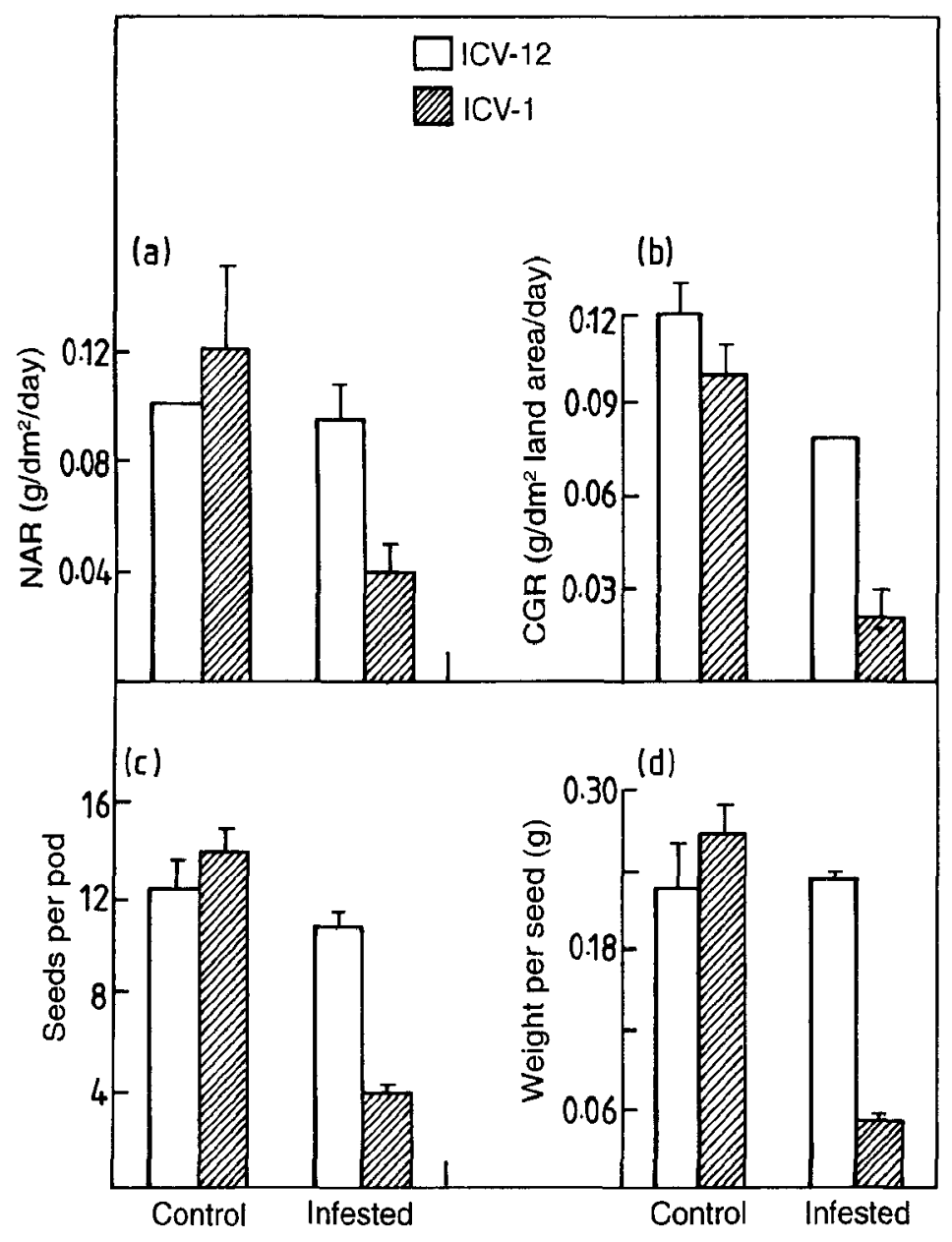

Fig. 1. Interactions of cowpea cultivar (cv. ICV-12 and cv. ICV-1) and treatment (aphid infestation and control) on growth and yield parameters of aphid-resistant (ICV-12) and aphid-susceptible (ICV-1) cowpea cultivars: (a) net assimilation rate $\left[\mathrm{NAR}\left(\mathrm{g} / \mathrm{dm}^{2} /\right.\right.$ day]; (b) crop growth rate [CGR in $\mathrm{g} / \mathrm{dm}^{2}$ land surface/day]; (c) seeds per pod; and (d) weight $(\mathrm{g})$ per seed; (means $\pm 95 \%$ C.I.) 
and the number of natural enemy species recorded $(r$ $=0.37,0.05<\mathrm{P}<0.25$ ), and the abundance of Cheilomenes spp. $(r=0.35,0.05<\mathrm{P}<0.25)$.

Plant mortality in the infested ICV-12 plants was $3 \%$ of the mortality in the control treatments. The mortality level in each of these treatments was significantly lower than that in infested ICV-1 plants by $4.2,11$ and $8 \%$ at the seedling, flowering and podding stages respectively (Table 2 ). There was also a positive correlation between aphid infestations and cowpea plant mortality $(r=0.89, \mathrm{P} \leq 0.001)$.

The ANOVA indicated significant interactions between cultivar and treatment for NAR $\left(F_{1,400}=\right.$ $14.36, \mathrm{P}<0.05)$, seeds per pod $\left(F_{1,1335}=8.60, \mathrm{P} \leq\right.$ $0.001)$ and weight per seed $\left(F_{1,1335}=15.04, \mathrm{P} \leq\right.$ $0.001)$, but not for CGR $\left(F_{1,392}=1.25,0.05<\mathrm{P}<\right.$ 0.10 ) (Fig. 1). At the 95\% C.I., growth was significantly reduced in infested plants of $\mathrm{cv}$. ICV1 for both NAR and CGR, and in ICV-12 for CGR, compared with the corresponding controls. However, there was no difference between infested and uninfested plants of $\mathrm{cv}$. ICV-12 for NAR. Yields of infested ICV-12 plants were significantly higher than those of infested ICV-1 plants, and did not significantly differ from the yields of the uninfested controls (Fig. 1).

Significant interactions were detected between cultivar and plant stage at infestation for seeds per $\operatorname{pod}\left(F_{1,1335}=31.51, \mathrm{P} \leq 0.001\right)$ and weight per seed $\left(F_{1,1335}=22.81, \mathrm{P} \leq 0.001\right)$. Analysis of the data by plant stage at infestation revealed significant $(\mathrm{P} \leq$ 0.05 ) differences in growth responses of the test cultivars at the seedling stage, with ICV-12 plants showing significantly greater growth and producing higher yields than ICV-1 plants. However, no significant differences were detected between the two cultivars at flowering or podding stages (Fig. 2).

There were significant interactions between treatment and plant stage at infestation for both seeds per pod $\left(F_{1,1333}=26.84, \mathrm{P} \leq 0.001\right)$ and seed weight $\left(F_{1,1335}=17.23, \mathrm{P} \leq 0.001\right)$. Using the $95 \%$ C.I., it was observed at each plant growth stage that

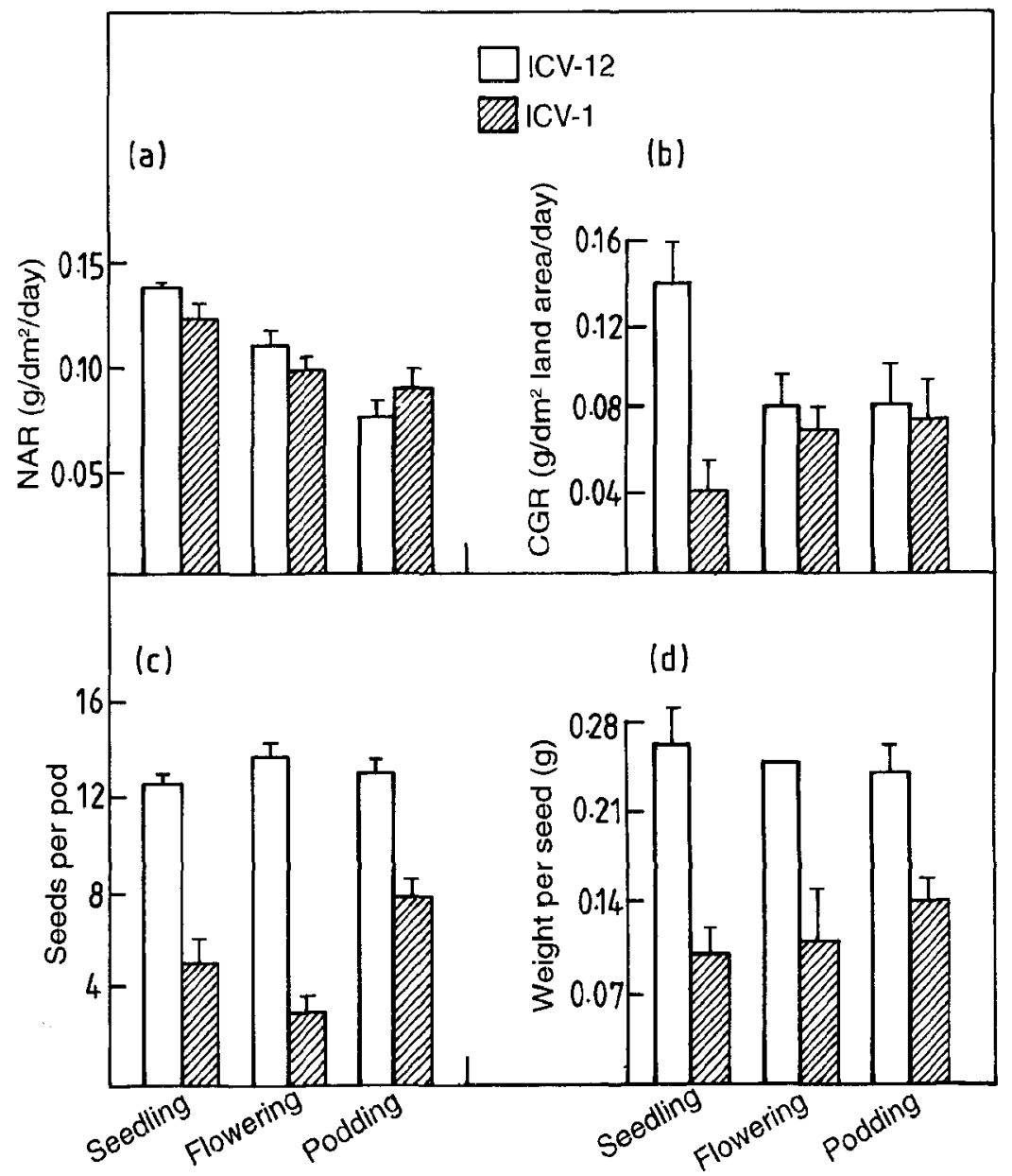

Plant growth stage at infestation

Fig. 2. Comparison effects of cultivar selections (cv. ICV-12 and cv. ICV-1) on growth and yield parameters of plants that received aphid treatments at different growth stages: (a) net assimilation rate [NAR(g/dm $/ \mathrm{day}]$; (b) crop growth rate [CGR in $\mathrm{g} / \mathrm{dm}^{2}$ land surface/day]; (c) seeds per pod; and (d) weight (g) per seed; (means $\pm 95 \%$ C.I.) 
aphid infestations significantly reduced crop growth and yield parameters (data not shown).

At each plant stage, counts of all aphid morphs were significantly higher on ICV-1 than on ICV-12.
Aphid colonisation was poorest on ICV-12 seedlings (Fig. 3). Nymphs were the most abundant stage of the aphid on both cultivars at all growth stages. Densities of apterous and alate aphids were highest

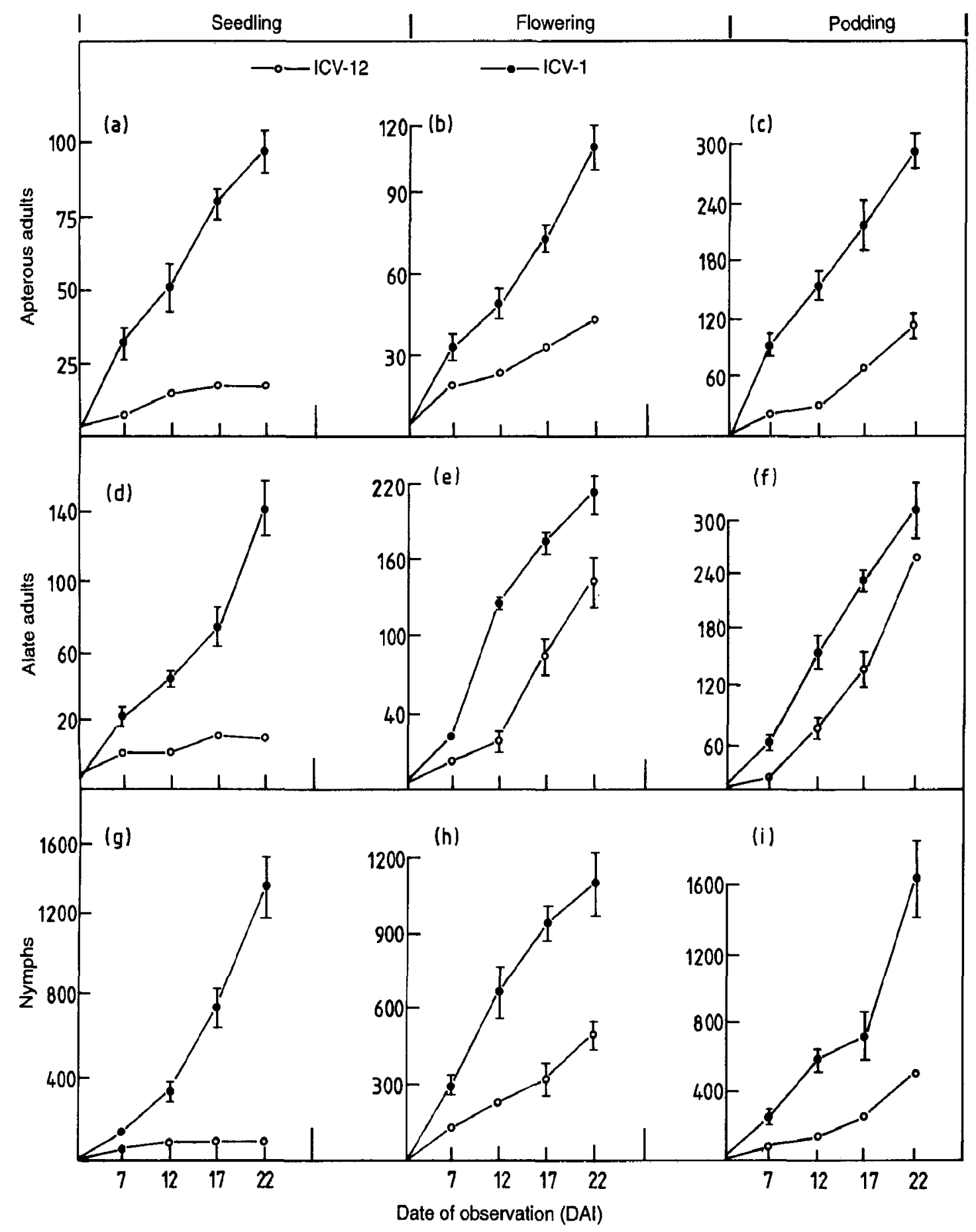

Fig. 3. Counts of different morphs (apterous adults, alate adults and nymphs) of cowpea aphid on plants of $\mathrm{cv}$. ICV-12 and cv. ICV-1 at seedling, flowering and seedling growth stages, at different dates of observation (days after infestation, DAI); $[\sqrt{ }(\mathrm{Y}+0.5)$ transformed data, means of transformed data were reconverted to original scale], (means $\pm 95 \%$ C.I.) 
on podding plants, while the abundance of alate aphids on ICV-12 plants increased sharply at the later plant stages (flowering and podding). In general, counts of all aphid stages and morphs increased linearly over time on both cultivars but colonisation was significantly faster on plants of $\mathrm{cV}$. ICV-1 than on plants of cv. ICV-12 at all plant stages (Fig. 3).

\section{DISCUSSION}

The trends of adverse effects of aphid infestations on the primary growth of plants (represented by ELHs), biomass accumulation (NAR and CGR), and yields (seeds per pod and weight per seed) of cowpea plants were similar to those observed by Hawkins et al. $(1985,1986 \mathrm{a}, \mathrm{c}, \mathrm{d})$. Although these workers did not find significant differences between infestations and control treatments for leaf area expansion, the results of their work suggest that all growth parameters of ICV-1, and CGR of ICV-12 were adversely affected. Thus varietal differences and plant stage at aphid infestation modulated damage caused by the pest to plant growth, yield and other factors associated with cowpea performance.

The incidence of sooty mould, even on uninfested plants in this study, indicated that establishment of moulds on leaves is not entirely associated with honeydew produced by aphids during infestation. Other factors including moisture condensation on leaves cause surface wetness and promote the trapping of fungal spores on leaf surfaces, and thus could also be contributing factors. However, the high correlation between aphid density and incidence of sooty mould on plants suggested that large amounts of honeydew produced at high levels of aphid infestation contributed greatly to aggravating the severity of sooty mould on plants.

Secondary infestations and transmission of diseases within fields are effected by apterous aphids, and alates contribute to the spread of diseases between fields (Atiri et al., 1986). Resistance in ICV-12 seedlings resulted in poor colonisation of plants by all stages and morphs of the aphid, including the apterae. Thus, reducing aphid populations can greatly reduce virus spread within and among cowpea fields. Apart from the use of resistant cultivars and timing of aphid infestations, it has been reported that secondary weed hosts and intercropping also affect the build-up of aphid populations (Ofuya, 1988, 1991). The aphid-borne mosaic was not observed in any of the plots. It was therefore not possible to establish whether virus transmission cancelled any advantages of using aphid-resistant cultivars or plant stages in conjunction with crop phenology to promote cowpea performance.
The high incidence of Cheilomenes spp. on infested ICV-1 plants, and on flowering and podding stages of ICV-12 suggested a density-dependent positive correlation between aphid density and abundance of the predator population at those growth stages. According to Perring et al. (1988), plant age may also influence interactions between aphids and their natural enemies. Juso and Norton (1987) reported that although natural enemies were important in controlling initial aphid populations, predators and parasites could not cope with sharp increases in aphid numbers, especially in the lateseason. The observation in this study that the trends of $A$. craccivora populations increase over time were similar to findings by Srikanth and Lakkundi (1990). Production of alate populations is usually in response to unfavourable environmental factors such as overcrowding, adverse weather, a decline in nutritional status of host plants or plant senescence. Production of alate aphids usually precedes aphid migration to colonise new host substrates. Thus, the greater abundance of alates at the later plant stages (flowering and podding) observed in this study (Fig. 3 ), was perhaps in preparation for emigration to find new resources.

\section{CONCLUSION}

This study established that cultivar selection and plant growth stage at aphid infestation are essential factors to be considered in developing guidelines for the integrated management of $A$. craccivora on cowpeas. Aphid densities and damage to crops can also be managed by combining host plant resistance with various complementary agronomic practices including planting date, no-till, inter-cropping, fertiliser applications and irrigation management (Burton et al., 1990; Ofuya 1991).

Acknowledgements-The authors are grateful to the Rockefeller Foundation, the Institute for African Development and Centre of International Studies at Cornell University, and the First Presbyterian Church of Ithaca, for financial support. Grateful appreciation is also due to $\mathrm{K}$. Ampong Nyarko, Edward F. Dwumfour, S. Oghiakhe, S. Firempong, R.S. Pathak, J. C. Olela, and K. V. Seshu Reddy for support and advice, and to Paul S. Taylor and J. Lindsey Flexner for their critical review of the manuscript. We are grateful to Charles O. Ouma, Ruben Ndenga, Silas P. Ojwang, Cleophas N. Oduor, Charles Ondiek, Nicholas Odhiambo, Philip Othieno, John Odera, Peter Nyongesa, E. G. Kabiru and other staff at MPFS for technical assistance. 


\section{REFERENCES}

Appiah M. R. and Thompson E. J. (1974) The effect of successive cropping on solid organic phosphorus. Ghana J. Agric. Sci. 7(1), 25-30.

Atiri G. I., Enobakhare D. A. and Thottappilly G. (1986) The importance of colonizing and noncolonizing aphid vectors in the spread of cowpeaaphid-borne mosaic virus in cowpea Vigna unguiculata. Crop Protection 5(6), 406-410.

Blackman R. L. and Eastop V. F. (1984) Aphids on the World's Crops - An Identification Guide. John Wiley and Sons, New York.

Brockman F. E. (1975) Grain legume improvement in Tanzania. In Proceedings of IITA Collaborators Meeting on Grain Legume Improvement, IITA, Ibadan, Nigeria; June 9-13, 1975. (Edited by Luse R. A. and Rachie K. O.). pp. $150-152$.

Burton R., Burg J. D., Jones O. R. and Wicks G. A. (1990) Crop production strategies for managing greenbug (Homoptera: Aphididae) in sorghum. J. Econ. Entomol. 83(6), 2476-2479.

Edwardson J. R. and Christie R. G. (1986) Viruses Infecting Forage Legumes. Monograph No. 14, Vols. 1-3. Agricultural Experiment Station and Institute of Food \& Agricultural Sciences, University of Florida, Gainesville, USA. 742 pp.

Gardner F.P., Pearce R. B. and Mitchell R. L. (1985) Physiology of Crop Plants. Iowa State University Press, Ames.

Hawkins C. D. B., Aston M. J. and Whitecross M. I. (1985) Aphid-induced changes in growth indices of three leguminous plants unrestricted infestation.CanadianJ.Bot.63(12), 2454-2459.

Hawkins C. D. B., Whitecross M. I. and Aston M. J. (1986a) Long-term effects on cowpea plant Vigna unguiculata growth of a short-term cowpea aphid Aphis craccivora infestation. Canadian J. Bot. 64(8), 1727-1732.

Hawkins C. D. B., Whitecross M. I. and Aston M. J. (1986b) Interactions between aphid infestation, plant growth stage and uptake of nitrogen and phosphorus by three leguminous host plants. Canadian J. Bot. 64(10), 2362-2367.

Hawkins C. D. B., Aston M. J. and Whitecross M. I. (1986c) Short-term effects of two aphid species on plant growth and root respiration of three leguminous species. Physiologica Plantarum 67(3), 447-452.

Hawkins C. D. B., Aston M. J. and Whitecross M. I. (1986d) Short-term effects of infestation by two aphid species on plant growth and shoot respiration of three legumes. Physiologica Plantarum 68(2), 329-334.
Hawkins C. D. B., Whitecross M. I. and Aston M. J. (1987a) The effect of short-term aphid feeding on partitioning of carbon ${ }^{14}$ dioxide photoassimilate in three legume species. Canadian $J$. Bot. 65(4), 666-672.

Hawkins C. D. B., Aston M. J. and Whitecross M. I. (1987b) Short-term effects of aphid feeding on photosynthetic carbon dioxide exchange and dark respiration in legume leaves. Physiologica Plantarum 71(3), 379-383.

Hughes S. J. (1976) Sooty moulds. Mycoae (Mycologia) 68(4), 693-820.

Juso M. M. and Norton G. A. (1987) Cabbage aphid control on commercial farms in the Thames Valley, UK. Crop Protection 6(6), 379-387.

MacFoy C. C. A. and Dabrowski Z. T. (1984) Preliminary studies on cowpea resistance to Aphis craccivora Koch (Homoptera: Aphididae). Z. Angew. Entomol. 97, 202-209.

Ofuya T. I. (1988) Occurrence, growth and survival of Aphis craccivora (Homoptera: Aphididae) on some weeds in a rain forest area in Nigeria. Ann. Appl. Biol. 113, 229-233.

Ofuya T. I. (1989) The effect of pod growth stages in cowpea on aphid reproduction and damage by the cowpea aphid, Aphis craccivora (Homoptera: Aphididae). Ann. Appl. Biol. 115, 563-566.

Ofuya T. I. (1991) Observation on insect infestation and damage in cowpea Vigna unguiculata intercropped with tomato Lycopersicon esculentum in a rain forest area of Nigeria. Experimental Agriculture 27(4), 407-412.

Ofuya T. I. (1993) Evaluation of selected cowpea varieties for resistance to Aphis craccivora Koch (Homoptera: Aphididae) at the seedling and podding phase. Ann. Appl. Biol. 123, 19-23.

Okigbo B. N. (1979) The role of grain legumes in the sub-humid semi-arid and arid areas of tropical Africa. In Soil Microbiology and Plant Nutrition: Symposium Proceedings, Kuala Lumpur, 1975. University of Malaya Press, pp. 585-602.

Pathak R. S. (1988) Genetics of resistance to aphid in cowpea. Crop Science 28(3), 474-476.

Pathak R. S. and Olela J.C. (1986) Registration of 14 cowpea cultivars. Crop Science 26, 647-648.

Perring T. M., Farrar C. A. and Toscano N.C. (1988) Relationships among tomato planting date, potato aphids (Homoptera: Aphididae), and natural enemies. J. Econ. Entomol. 81(4), 1107-1112.

Rachie K. O. (1973) Improvement of food legumes in tropical Africa. In Nutritional Improvement of Food by Breeding. Proc. Symp. Sponsored by PAG, Rome, Italy; July 3-5, 1972. Protein Advisory Group of the United Nations, New York, pp. 83-92. 
Raheja A. K. and Leleji O. I. (1974) An aphid-borne virus disease of irrigated cowpea in Northern Nigeria. Plant Dis. Rep. 58(1), 1080-1084.

SAS Institute (1994) JMP ${ }^{\mathrm{TM}}$ Statistics and Graphics Guide. Version 3.0.2. SAS Institute Inc., Cary, N. C. $580 \mathrm{pp}$.

Singh S. R. (1975) A proposal for integrated control of cowpea insect pests. In Proceedings of IITA Collaborators Meeting on Grain Legume Improvement, Ibadan, Nigeria; June 9-13, 1975.
(Edited by Luse R. A. and Rachie K. O.), pp. 4143.

Snedecor G. W. and Cochran W. G.(1980)Statistical Methods. 7thedition. Iowa State University Press, Ames, IA. $507 \mathrm{pp}$.

Srikanth J. and Lakkundi N. H. (1990) Seasonal population fluctuations of cowpea aphid, Aphis craccivora and its predatory coccinellids. Insect Sci. Applic. 11(1), 21-26. 